\title{
Introduction: Global Health and Human Rights
}

Lawrence O. Gostin

Georgetown University - Law Center - O'Neill Institute for National and Global Health Law, gostin@law.georgetown.edu

Benjamin Mason Meier University of North Carolina at Chapel Hill, bmeier@unc.edu

This paper can be downloaded free of charge from: https://scholarship.law.georgetown.edu/facpub/2327 https://ssrn.com/abstract=3634292

Lawrence O. Gostin \& Benjamin Mason Meier, Introduction: Global Health \& Human Rights, in Foundations of Global Health and Human Rights 1-19 (Lawrence O. Gostin \& Benjamin Mason Meier eds., New York: Oxford University Press 2020).

This open-access article is brought to you by the Georgetown Law Library. Posted with permission of the author. Follow this and additional works at: https://scholarship.law.georgetown.edu/facpub

Part of the Health Law and Policy Commons, and the International Humanitarian Law Commons 


\title{
Introduction
}

\section{Global Health and Human Rights}

\author{
Lawrence O. Gostin and Benjamin Mason Meier
}

Global health and human rights are complementary approaches to advancing physical, mental, and social well-being throughout the world. Through efforts to advance public health in a globalizing world, global health seeks to improve the underlying conditions that contribute to the health of populations, supporting the most vulnerable to achieve justice in health. Human rights offer universal legal frameworks to advance justice, elaborating the freedoms and entitlements necessary to realize dignity for all. These international human rights standards have been shown repeatedly to influence global health-framing health concerns within the policy environment, integrating legal norms in public health practice, and facilitating accountability for realizing the highest attainable standard of health. It is impossible to understand global health without understanding its human rights foundations, and, likewise, it is impossible to understand human rights without understanding its necessary application to global health. This foundational text provides an introduction to the interconnected relationships between global health and human rights.

The field of health and human rights-by examining interdisciplinary approaches to achieve individual dignity, social justice, and public health-has found broad acceptance in academic discourse and proven highly influential in health policy. Where human rights are central to public health, governments are called upon to find ways to conform public health practice to human rights standards. Addressing public health as a matter of human rights, international law has offered global standards by which to frame government responsibilities and evaluate health policies, shifting the health debate from political aspiration to legal accountability. As a basis for global justice under international law, it is necessary to understand the development of human rights norms and principles that frame global health; the implementation of human rights in public health policy and practice; and the application of human rights to disease prevention and health promotion-examining the rapid evolution of the field and the rising imperative for future progress.

This introduction highlights the foundational importance of human rights for global health and provides an academic framework for this book by laying out the role of human rights under international law as a basis for public health. Part I seeks to define the evolving conceptualization of health, examining both the shifting focus from medicine to public health and the shifting response from international health to global health. Framing global health as a human rights imperative, Part II examines the establishment of human rights under international law, the implementation of these rights in 
public policy, and the development of rights for public health. With this development of human rights giving rise to the field of "health and human rights," Part III explores the recent birth of this interdisciplinary field, creating a field of practice that now requires a formal academic foundation. Part IV describes the academic contribution of this foundation text to the field and outlines the structure of this comprehensive volume, delineating the chapters that describe the normative development, policy implementation, contemporary application, and new challenges in the field. This introduction concludes by reaffirming the inextricable linkages between health and human rights, calling on scholars, practitioners, and advocates to work together to advance human rights in global health.

\section{Global Health Is Public Health}

Health is a state of complete physical, mental, and social well-being-structured by individual, interpersonal, community, and institutional factors interacting with local, national, and global environments. Beyond individual medical care, health is influenced most strongly by underlying determinants of the public's health, including a wide array of social, economic, and political forces. Addressing public health in a globalizing world, global health looks beyond the actions of individual nations to encompass the larger set of determinants that affect the health of the entire world.

\section{A. From Medical Care to Public Health}

Concerned with the health of the population as a whole, public health reflects societal efforts to prevent disease and promote health through the improvement of underlying determinants of health. These determinants include a range of social, economic, and political factors such as household income level and stability, access to high-quality education and health care services, and the safety of natural and built environments. In structuring these determinants of health, public health seeks to assure the underlying conditions through which the population can be healthy (Detels and Tan 2015). This mission implicates the needs and expectations of the entire population, requiring collective action through public policy to meet the health needs of all people. Yet, the practice of public health has evolved dramatically over the centuries to reflect changing health theories, threats, and technologies.

Dating back to the earliest civilizations, humans have been challenged by factors that impact the health of the public. With understandings of disease shifting from divine forces to natural causes, Greco-Roman philosophers posited that poor health was the result of an "imbalance between man and his environment" (Rosen 1958, 33), seeking to monitor the physical and environmental factors believed to influence health. As infectious diseases continued to ravage the overcrowded medieval cities of Europe through the Middle Ages, governments developed quarantine and isolation measures as a basis to protect the public's health. The Enlightenment and Industrial Revolution thereafter gave rise to a sanitary reform movement that linked 
poor health to inadequate social and environmental circumstances amidst urbanization and industrialization. This sanitary movement galvanized efforts to improve hy leading to the establishment of the first health departments to oversee public health systems (Winslow 1924). Disease thus came to be seen as a societal rather than a personal issue, and the growing importance of sanitation gave rise to government efforts to improve the conditions in which people lived-through policy reforms and public infrastructures.

As scientific discovery in the late nineteenth century came to support the identification of disease-causing agents, these scientific advances became the means to realize societal goals of disease prevention. Drawing on government record keeping, statistical analysis used data on morbidity and mortality (sickness and death) to lay the foundations of epidemiology, which examined the determinants and distribution of health patterns and analyzed health outcomes across populations. Epidemiologic surveillance sought to track disease back to its source, recognizing the association between environmental factors, disease outbreaks, and individual mortality. Where morbidity and mortality were linked to poverty, malnutrition, and other societal ills, epidemiologists began to study the influence of these social factors (Sand 1934). Thus arose the field of social epidemiology, which sought to examine the correlations between socioeconomic conditions and disease incidence.

Social epidemiology provided statistical evidence of health inequalities, demonstrating the disproportionate harms affecting the working classes and the central importance of government health departments. This evidence provided the impetus at the opening of the twentieth century for broader societal efforts to preserve and promote the well-being of the population, giving rise to the modern field of public health. Despite the concurrent rise of modern medicine, epidemiologic data undercut the "triumphalist myths of clinical medicine" (Porter 1997, 102), highlighting how improvements in health were largely delivered by public health, rather than medical interventions. Given the limited influence of medicine on health outcomes, policymakers recognized that improvements in the health of populations would come from "modification of the conditions which led to disease, rather than from intervention in the mechanism of disease after it has occurred" (McKeown 1979, 198). The field of public health-examining biological, environmental, and societal factors as the determining basis of population health-came to embrace quantitative analysis through social epidemiology and policy response through "social medicine" (Susser and Susser 1996). Looking to improvements in nutrition, education, and living conditions, social medicine stressed the importance of a holistic understanding of health, bringing together social sciences with medicine to address underlying determinants of health.

Through an appreciation of the social, economic, and political conditions that underlie health, public health practice now examines interactions across underlying determinants of health and designs policy interventions to address disease prevention and health promotion. By focusing on structural determinants of health, it has become clear that public health is inseparable from socioeconomic context, with poverty standing as a fundamental underlying determinant of health (Meyer and Schwartz 2000). Through inequities in resources, power, and privilege, those living in poverty lack access to underlying determinants of good health, restricting their capability to 
determine their own health status. ${ }^{1}$ Thus, it has become a maxim of public health that no matter the disease-acute, chronic, communicable, non-communicable-or from where it originates, it will inevitably descend the social gradient to become a disease of the poor (Marmot, Kogevinas, and Elston 1987). This societal framing of inequality "implicates our collective responsibility for unhealthy behavior," with public health practitioners examining structural determinants of health, including "the way society organizes itself, produces and distributes wealth, and interacts with the natural environment" (Gostin, Burris, and Lazzarini 1999, 64).

\section{B. From International Health to Global Health}

Global health has adopted this societal approach to understanding global determinants of public health, expanding far beyond the limited origins of international health from which it arose. Shaped by the contemporary phenomenon of globalization, the interconnections across nations and populations have become essential to the field of global health, recognizing that all countries face common public health threats (Frenk and Moon 2013). Where these threats require collective action from a global range of stakeholders, global health governance has brought together national governments, intergovernmental organizations, and nongovernmental actors to mitigate transnational health threats.

International health was originally borne of a need to describe, study, and address the spread of disease between countries. Emerging with increases in international commerce during the mid-nineteenth century, the international spread of communicable diseases encouraged international cooperation to protect national interests from transnational health threats. Yet, with self-interest guiding national efforts to address communicable disease, international health could not conceptualize efforts to address the rising environmental, physical, social, cultural, and economic threats to public health in a globalizing world. Globalization-the complex phenomenon through which national societies have become increasingly interconnected and interdependent-has transformed public health by connecting countries in shared vulnerability (Birn, Pillay, and Holtz 2017). Through these rapidly globalizing forces, infectious disease agents could spread farther and faster than ever before, pollution could threaten environments throughout the world, and economic systems could cause financial shocks across nations.

Domestic responses to these globalized health threats are often inadequate given the limited ability of national governments to respond on their own to globalized determinants of health (McMichael and Beaglehole 2009). Where international health efforts proved unsuccessful in protecting countries from health threats across nations, there arose a need at the end of the twentieth century to establish new frameworks for health cooperation. In responding to these globalized health threats, the shift toward "global health" has sought to describe the ideas of collective action and the underlying determinants of health for all peoples, rather than those of particular countries (Brown, Cueto, and Fee 2006).

\footnotetext{
1 The term "structural violence" has been used to highlight the violence to health that arises from unjust inequalities based on power, wealth, and privilege, including those rooted in gender, race, ethnicity, religion, and social class (Farmer 2003).
} 
Reflecting the globalization of the public health response, the field of global health involves the study, research, and practice of public health that prioritizes the improvement of health and health equity for all people globally. Global health thus takes into account and upholds the primary tenets of the field of public health on a global scale: determinants of health, preventative measures, and health systems. ${ }^{2}$ By expanding transnational health concerns to include threats as diverse as antimicrobial resistance, non-communicable diseases, and climate change, the field of global health seeks to bring together a multitude of actors to prioritize the improvement of health determinants and the achievement of health equity for all people worldwide (Fried et al. 2010). Rather than relying solely on individual countries and health systems, global health calls for the collective effort of national governments, international organizations, and nongovernmental institutions to achieve shared public health goals. Such coordination of global health stakeholders to manage globalized health concerns has created an imperative for global governance.

Global health governance is capable of addressing interconnected determinants of health through collaboration, with local, national, and international actors partnering and integrating their actions to form a global governance structure that seeks to mitigate the global threats that undermine public health. This global governance stems from international organizations that provide normative frameworks for global health policy, humanitarian initiatives, and development assistance in order to promote public health in a rapidly globalizing world (Youde 2012). The World Health Organization (WHO), as the leading public health authority within the United Nations (UN), maintains a key role in partnering with a diverse range of actors to coordinate global responses to shared public health challenges. Beyond WHO, global institutions have proliferated in addressing global determinants of health, forming complex governance structures that frame health policies, programs, and practices (Moon et al. 2010).

This interdependent system of global health governance has become a basis to realize a more just world through public health, with human rights legitimating and framing cooperative actions. Global health and human rights have thus become intertwined, with the enjoyment of human rights influencing public health, and public health influencing the enjoyment of human rights. This "rights-based approach to health"-derived from the human right to health and rights to underlying determinants of health-provides guidance to this multilevel and multi-sectoral governance landscape for global health and facilitates accountability for the protection and promotion of public health (Meier and Gostin 2018).

\section{Human Rights as a Basis of Global Health}

Human rights have evolved to provide a framework for justice in health policies, programs, and practices. Where health is shaped by a range of interconnected

${ }^{2}$ Where policymakers have continued at times to seek narrow medical interventions to address specific health threats, this "vertical" approach to health has been critiqued for prioritizing the treatment of specific diseases while failing to consider the determinants that are the root cause of global health disparities. By contrast, public health proponents have looked to "horizontal" approaches to create a system of sustainable structures to address determinants of health (Frenk, Gómez-Dantés, and Moon 2014). 
determinants that extend beyond medical care, human rights-through their recognition of these interconnected determinants-offer a comprehensive framework for defining and understanding the holistic factors that shape public health and well-being. Human rights have therefore become central to global health. By addressing issues in public health as a matter of human rights, these health-related human rights ${ }^{3}$ have developed under international law, been implemented in public policy, and facilitated accountability for health outcomes.

\section{A. Framing Justice through Human Rights}

Human rights offer universal legal frameworks to advance justice in health. All human beings-regardless of their national origin, race, gender, or other status-are entitled to specific rights and freedoms. Instrumental to human dignity, human rights seek to address basic needs and frame necessary entitlements to uphold a universal moral vision, reflecting what a person is entitled to have, do, or receive (Donnelly 2003). As a foundation for justice under law, these rights and freedoms are:

- Universal (human rights apply to all people, everywhere),

- Inalienable (human rights cannot be taken away),

- Indivisible (human rights have equal status), and

- Interdependent (the realization of each human right depends on the realization of other human rights).

Drawing from the long fight for justice over the centuries, human rights establish a normative foundation for contemporary understandings of global justice. The central moral basis for human rights is dignity - that all humans are born equal in dignity, and thus live equal in rights. Concerned with an individual's intrinsic importance, value, and ability to self-govern within a particular social context, dignity provides a foundation for understanding what it means to be human (Habermas 2018). The conditions for facilitating the realization of human rights involve government action (or inaction) to respect individual freedoms, protect individuals and groups, and fulfill basic needs (Steiner, Alston, and Goodman 2008). By setting global norms to realize the inherent dignity of all individuals, human rights standards conceptualize health disparities as "rights violations," offering normative standards to frame legal accountability for the realization of these rights.

Human rights law, by defining social harms as international legal violations, contributes to social justice by formalizing norms of justice and facilitating accountability for their realization. Reflecting philosophical efforts to achieve a more fair and equitable world, social justice efforts seek to alleviate inequities within and between countries (Ruger 2018), recognizing the ways in which societal power dynamics can create and perpetuate conditions that deprive people of freedom and human dignity. While social justice emphasizes the elimination of social inequality, human rights

\footnotetext{
3 This volume employs the term "health-related human rights" to refer to the wide range of civil, political, economic, social, and cultural rights that underlie public health.
} 
provide an examination of the specific government responsibilities to create conditions necessary for realizing human dignity. Human rights law establishes a legal commitment that defines what governments must do-or must not do-not only to redress the suffering of those who are most vulnerable but also to ensure the inherent dignity and equal rights of all (Yamin 2016). Because human rights are developed and adopted by the governments that seek to implement them, they are viewed as a legitimate standard against which to assess government conduct. Codifying human rights under law thus creates a binding political basis from which legal accountability for social justice can be assured. Where social justice incites change from the "bottom-up," driven by those who are most affected by social inequality, human rights law incites change from the "topdown," with governments creating a set of international legal standards to frame their actions.

Reflecting a shared global vision for the promotion and protection of human dignity, international human rights law follows a set of internationally agreed-upon treaties and conventions that are informed by national practice and interpreted by formal institutions. National governments-or states ${ }^{4}$-are the primary duty-bearers under human rights law, assuming international legal obligations to respect, protect, and fulfill human rights. This legal framework empowers individuals to seek redress for rights violations and hold governments accountable for rights realization, complementing social justice efforts through the development of international human rights law (Gostin 2001).

\section{B. Developing Health-Related Human Rights to Support Public Health}

Human rights law has evolved dramatically through the UN—from political aspiration to legal entitlement-profoundly influencing health. The codification of human rights for global health first emerged in the aftermath of World War II, with rights providing a formal legal basis for assessing and adjudicating principles of justice (Donnelly 2003). Working through the newly formed UN system, states came together to proclaim and elaborate human rights under international law. As a part of this new UN structure, states established WHO to coordinate international responses to transnational health threats. The 1946 Constitution of the World Health Organization became the first international treaty to conceptualize a human right to health, with states declaring that "the enjoyment of the highest attainable standard of health is one of the fundamental rights of every human being" (WHO 1946, preamble). In binding the postwar world together through human rights, states thereafter created "a common standard of achievement for all peoples and all nations," setting forth a universal vision of human rights for the first time in the 1948 Universal Declaration of Human Rights (UDHR) (UN General Assembly 1948, preamble). The UDHR situated health under the right to an adequate standard of living, declaring that "everyone has the right to a standard of living adequate

${ }^{4}$ Reflective of international legal discourse, this volume employs the term "states" to refer to national entities that have a defined territory, population, and government and can enter into relations with other states through international law. 
for the health and well-being of himself and of his family" (Ibid., art. 25). By focusing on the universally shared principles underlying human dignity, the UDHR created a foundation to advance human rights for public health.

Despite the early promise of human rights to advance health, human rights efforts would soon be challenged by the rapidly escalating Cold War. As states moved to develop human rights treaties, strong ideological tensions between states-driven by the Cold War superpowers (the United States and Soviet Union) — challenged this effort to make human rights binding under international law. The Soviet Bloc ideologically favored economic and social rights whereas the Western states embraced civil and political rights (Steiner, Alston, and Goodman 2008). ${ }^{5}$ Through nearly two decades of negotiations, the UN sought to bridge these divergent rights-based ideologies by adopting two separate human rights covenants, establishing in 1966 the International Covenant on Civil and Political Rights (ICCPR) and the International Covenant on Economic, Social and Cultural Rights (ICESCR). These two documents, referred to collectively with the UDHR as the "International Bill of Human Rights," lay out the basic rights of the modern human rights system. Given these disagreements in international relations on the nature of rights, the ICESCR resulted in a narrow definition of the right to health, with states recognizing only "the right of everyone to the enjoyment of the highest attainable standard of physical and mental health" and limiting the progressive realization of this right to a narrow set of determinants of health (UN General Assembly 1966, art. 12).

However, in the years following the ICESCR, the human right to health continued to evolve under international law in light of shifting definitions of health and the obligations necessary for its realization. The 1978 Declaration on Primary Health Care (also called the Declaration of Alma-Ata) reaffirmed and elaborated the right to health by emphasizing the necessity of broad-based socioeconomic development to build sustainable, comprehensive primary health systems (WHO 1978). As human rights flourished in the 1990s following the end of the Cold War, a range of normative developments joined civil and political rights with economic, social, and cultural rights, recognizing the ways in which these two sets of rights are interconnected and interdependent. The 1993 International Conference on Human Rights, resulting in the Vienna Declaration and Programme of Action, memorialized global consensus on the indivisibility of civil, political, economic, social, and cultural rights (UN General Assembly 1993). This consensus would later be reaffirmed by the UN Committee on Economic, Social and Cultural Rights, which issued General Comment 14 to provide authoritative interpretation of state obligations under the right to health in the ICESCR. General Comment 14 clarified that the right to health depends on a wide variety of interconnected rights for the public's health, including rights to preventive and curative health care and also rights to underlying determinants of health such as housing and access to information (CESCR 2000). Thus, for states to create an environment conducive to good health, they must establish an expansive health system, realizing the economic, social, cultural, civil, and political rights that underlie the public's health (Marks 2001). These developments broadened human rights to uphold underlying determinants of

\footnotetext{
${ }^{5}$ As this distinction is elaborated throughout this volume, civil and political rights were thought to require only the abstention of state action while economic, social, and cultural rights were seen to require affirmative state action based upon available resources (Marks 2009).
} 
health under international law, providing an international legal basis to frame national obligations to implement human rights for public health.

\section{Implementing Human Rights in Public Health Policy and Practice}

Human rights law provides a framework to advance policy and practice for global health, but the realization of human rights requires state implementation. Following from the dramatic development of health-related human rights, the UN human rights system has shifted from the development of human rights under international law to the implementation of those rights through public policy and state practice. State implementation of international human rights law requires governments to operationalize human rights obligations in domestic policies, programs, and practices. Human rights implementation is not automatic; it requires progressive actions by governments to realize human rights in the lives of individuals (Getgen and Meier 2009).

With international human rights law evolving to address globalized threats to health, the implementation of human rights transforms the power dynamic that underlies public health. Identifying rights-holders and their entitlements as well as duty-bearers and their obligations, a rights-based approach to health establishes that universal respect for human dignity and the advancement of human well-being are not simply matters of benevolence, but are obligations under law (Mann 1994). Through this legal framing, state duty-bearers must meet their obligations to realize health-related human rights to the maximum of their available resources. As a result, policymakers have been pressed to implement health-related human rights through national policies, assuring that healthcare facilities, goods, and services are available, accessible, acceptable, and of sufficient quality (Backman et al. 2008). As a framework for global health governance, state governments, international organizations, and even nonstate actors have increasingly invoked a rights-based approach to health. This rights-based approach has provided normative clarity in public health policy and legal accountability for public health outcomes (Meier et al. 2018).

The links between global health and human rights are now firmly established in international law, national policy, and public health practice, yet the implementation of human rights obligations necessitates accountability to assess human rights realization for public health promotion. Accountability seeks to ensure that states are both responsible and answerable for making human rights a reality in the lives of their people, providing a path for human rights threats and violations to be both identified and addressed (Yamin 2008). Through a range of monitoring, review, and adjudication mechanisms-at national, regional, and international levels of governance-states are required to demonstrate and justify how they have either realized, or taken steps to realize, their human rights obligations under international law. These accountability mechanisms seek to serve both corrective and preventive functions-providing remedies for human rights violations, as well as determining which aspects of national policy, programming, and practice need improvement (Potts 2008). In the absence of a global judiciary, these accountability procedures thus seek to encourage national implementation of international law and promote universal respect for human rights, 
creating a field of practice in which human rights can effectively frame health efforts as a means to advance global justice.

\section{A Field Is Born}

The field of health and human rights seeks to apply human rights under international law to advance the public's health. Despite the evolving development of human rights for global health, it was not until the 1980s that the health and human rights movement first began to take shape. This movement built upon the interdependent linkages between health promotion and human rights protection in the early years of the HIV/AIDS response. Reacting to the social injustices that were pervasive in responses to an unfolding AIDS pandemic, social movements increasingly claimed human rights as a common language to underpin demands for justice in health. From this early advocacy, professionals in both the public health and human rights fields began to acknowledge the complementarity of these two disciplines as dimensions of, and approaches to, human dignity and well-being (Yamin 2008). The resulting field of "health and human rights" would embrace the interdisciplinary connections between public health and human rights, viewing both as synergistic means to achieve shared objectives. This intersection between health and human rights was seen to provide practical benefits, not only in reframing thinking about major global health challenges but also in broadening human rights thinking and practice (Mann et al. 1994). ${ }^{6}$ Recognizing the interconnected relationships between health and human rights has offered new pathways for the advancement of human dignity amidst the challenges of a globalizing world. Through its evolution into the twenty-first century, the health and human rights movement has brought human rights norms and principles into a wide range of disease prevention and health promotion efforts throughout the world, with a growing body of evidence that demonstrates how human rights realization has been beneficial for population health (Meier et al. 2018).

As an academic discipline, the field seeks to advance understanding of the relationship between health and human rights, motivating engagement in both law and public health scholarship. Leading up to the birth of this movement, scholars long recognized the need for human rights education in the health professions. Although the significance of human rights for health has long been articulated under international law, health professionals with limited exposure to and knowledge of human rights principles were largely unaware of the ways in which human rights were connected to health practice. The importance of human rights education in medical and public health practice has since been recognized by a wide range of professional health organizations, and there have been calls for all health professionals to be exposed to human rights in their education (Iacopino 2002). The inclusion of human rights in health professional studies holds the potential to raise awareness of and engage professionals in human rights discourse, challenging the status quo and giving practitioners a set of practical

\footnotetext{
${ }^{6}$ Drawing on his leadership of the WHO Global Programme on AIDS Jonathan Mann sought to recognize the "inextricable linkages" between health and human rights, examining human well-being in ways that could not be conceptualized through an isolated health or human rights-based approach (Gruskin, Mills, and Tarantola 2007).
} 
competencies to identify and address issues of social justice in health. In doing so, the discipline of health and human rights could enable the incorporation of human rights principles into health practice, fostering a culture of human rights in the health sector (Tarantola and Gruskin 2006).

This academic field would build upon evolving international efforts to expand human rights education, with the UN looking to human rights education as a basis for moral solidarity and global justice. Where the UDHR enshrined education as a principal vehicle to foster respect for human rights, it became clear following the Declaration of Alma-Ata that health professionals in particular should understand health-related human rights, with WHO partnering with the UN Education, Science and Cultural Organization (UNESCO) to promote human rights education in healthcare settings (WHO 1980). Academic efforts to establish health and human rights coursework in graduate health education would soon follow. Beginning with a single course in 1991, ${ }^{7}$ health and human rights teaching expanded exponentially in the years that followed (Cotter et al. 2009). Subsequent health and human rights competencies not only established how the realization of human rights shapes the lived reality of health, but also sought to enable students to translate key human rights norms and principles into action-oriented health efforts (Tarantola and Gruskin 2006). Courses on health and human rights now exist throughout the world-at the undergraduate level and in a variety of professional schools, including in schools of law, policy, and medicinewith health and human rights analysis now included as a core competency of the US master of public health (MPH) curriculum (ASPH Education Committee 2006) and in curricula globally.

These educational efforts to mainstream human rights have expanded into the workforce, with professional associations embracing human rights in global health. Acknowledging the role that physicians and nurses play in protecting human rights, the World Medical Association and the International Council of Nurses have called upon medical and nursing schools to incorporate medical ethics and human rights education as core components of the curriculum (World Medical Association 1999). Within the discipline of public health, the American Public Health Association has sponsored education and practice initiatives in the field of health and human rights, releasing an early report to examine the educational challenges in teaching health and human rights (APHA and FXB Center 2002) and now mainstreaming the rights-based approach in practice through its Human Rights Forum. These efforts across professional organizations have contributed to the legitimacy of human rights as a foundation and framework for advancing justice through health practice, supporting the continuing expansion of the field of health and human rights.

Human rights now serve as a unifying framework to understand the role of health in society, presenting a powerful critique of iniquitous health practices and informing public health policy development. Where health policymakers and practitioners long lacked familiarity with human rights concepts and core documents-complicating efforts to negotiate the optimal balance between public health and human rights-human

\footnotetext{
7 Taught at Harvard University, the first course in this field sought to give an overview of the discipline, placing equal weight on the history of human rights, review of human rights instruments, and the debate between universalism and relativism (Brenner 1996).
} 
rights have provided a path for understanding the ways in which core public health responsibilities may burden or restrict human rights (Gostin 2014). By applying human rights norms and principles to evaluate the effects of health policies on human rights, those working to advance public health can develop effective strategies to realize human rights through public health policy. In turn, rights-based health policymaking provides guidance for public health practice, framing health efforts to respect, protect, and fulfill the human rights of individuals and populations (Gostin and Mann 1994). The acceptance of conceptual linkages between health and human rights has required practitioners in both communities to re-examine their definitions of health and the scope of their professional responsibilities. To this end, health professionals have increasingly addressed rights-based approaches to public health, especially in their work with marginalized populations, emphasizing individual empowerment, community participation, and government accountability (Frisancho, Goulden, and Gayle 2010). Correspondingly, human rights advocates have sought to identify public health data that indicate the progressive realization of health-related human rights, bringing human rights accountability to global health promotion. Linking the realization of human rights and promotion of public health has had strategic implications and practical consequences for global health and human rights.

Putting human rights norms and principles into practice in global health governance, the 2015 Sustainable Development Goals (SDGs) have mapped out a constellation of cross-cutting social, economic, and environmental objectives to establish a comprehensive global vision for achieving a more equitable world. The underlying focus on equity in the SDGs has created crucial opportunities to advance global justice through human rights. Providing a transformative foundation for human rights in global health, the SDGs seek to incorporate the obligations of the right to health as a foundation for the provision of universal health coverage, establishing a new global minimum standard for health (UN General Assembly 2015). ${ }^{8}$ The SDG targets are critical for the progressive realization of health-related human rights. While not explicitly framed as a part of international human rights law, the SDGs demonstrate renewed commitment to the relationship between health and human rights by addressing issues of human dignity and equality through a broad range of interrelated targets (Forman, Ooms, and Brolan 2015). Building upon efforts to overcome existing global health injustices through the SDGs, human rights efforts can guide the implementation of these goals through scholarship and policy debate on the necessary structures, politics, and processes to ensure that the SDGs are translated into reality (Winkler and Williams 2017). This critical engagement in global health can establish a stronger bridge between the achievement of the SDGs and realization of human rights, ensuring that governments are held accountable for addressing global health inequities.

The development of global health and human rights institutions has brought the world together, united in common goals for the protection of human rights and the advancement of global health; however, these developments now face challenges from

8 With the Millennium Development Goals expiring in 2015, the right to health contributed to critical gains in the post-2015 era, wherein human rights provided a path to introduce accountability mechanisms, prescribe a participatory process for the development of the SDGs, and ensure a focus on non-discrimination and equality rather than average country-level improvements (Forman 2011). 
rising populist forces. Ushered in on resurgent waves of racism, xenophobia, antiSemitism, and Islamophobia, right-wing populism seeks to retrench nations inward by promoting a nativist definition of the rights of citizenship (Alston 2017). In direct and violent contrast with the global solidarity attendant to health and human rights, populist politicians have sought to undermine the vision of a common humanity that has structured global governance over the past seventy-five years. Viewing human rights as an obstacle to nationalist policies, these politicians have attacked the universality of rights, undercutting the very foundation of the health and human rights movement. As liberal democratic values are displaced in global society, populist governments continue to violate human rights principles, restrict civil society advocacy, repress minority populations, attack gender equality, ignore scientific evidence, and neglect public health (Rodríguez-Garavito and Gomez 2018). Undermining efforts to implement human rights in global health, this nationalist retrenchment could lead to a rejection of both global governance and human rights as a basis for public health advancement (Meier et al. 2018). In responding to these threats, human rights education will be necessary to prepare practitioners to respond to this populist shift and engage with health and human rights discourse to ensure a future for human rights in global health.

\section{Structure of This Volume}

Building from the evolving linkages between global health and human rights, this volume looks to the role of human rights under international law as a basis for public health, providing a foundation for understanding the global standards by which to frame individual rights and government responsibilities for health. This volume is organized in four main sections: (1) explaining the norms and principles that define the field, (2) examining the methods and tools for human rights implementation and accountability, (3) applying human rights to contemporary public health threats, and (4) analyzing the rising human rights challenges of a rapidly globalizing world.

\section{Section I. Norms and Principles}

Section I introduces the reader to the normative foundations and legal principles for understanding the role of human rights in protecting and promoting public health. The first chapter provides a historical narrative of human rights leading up to the 1948 UDHR, examining the philosophical meaning of human rights by tracing the normative evolution of rights from individual freedoms against sovereign rulers to a vision that addresses the interconnected civil, cultural, economic, political, and social rights that underlie health. Following from the birth of the UN, Chapter 2 introduces the legal foundations of the book by laying out the role of human rights under international law, defining human rights as part of global health law by examining the translation of the UDHR into binding international legal standards for global health promotion. Having clarified the origins, definitions, and codifications of human rights, Chapter 3 introduces the reader to the right to health and other health-related human rights, 
chronicling the evolution of these rights to encompass a wide range of determinants of health. Chapter 4 concludes Section I, looking beyond the right to health to review the cross-cutting human rights principles that structure the rights-based approach to health, recognizing the importance of realizing human rights for public health promotion and exploring rights-based principles of equality and non-discrimination, participation, and accountability.

\section{Section II. Implementation and Accountability}

Shifting from the development to the implementation of human rights, Section II provides the reader with an understanding of the major tools and mechanisms to implement international human rights in national efforts and facilitate accountability for health and human rights. Chapter 5 discusses the importance of translating international law into domestic policy and considers national policy processes to translate human rights norms into public health practice. Where human rights activists long shunned health-related human rights, Chapter 6 explores the evolution of human rights advocacy for global health, examining the expanding range of advocacy tools to advance social justice through public health. Monitoring and review have become a principal basis of human rights accountability in global health, and Chapter 7 examines the importance of monitoring and review institutions and human rights indicators in facilitating accountability for the implementation of human rights. Chapter 8 looks to judicial efforts to provide accountability for health-related human rights, analyzing the opportunities and limitations of litigationdriven efforts to enforce human rights for health advancement. Global governance has become central to assuring human rights implementation throughout the world, and Section II concludes in Chapter 9's focus on global health governance, recognizing the mainstreaming of rights across the UN and the work of international organizations to implement health-related human rights in their policies, programs, and practices.

\section{Section III. Contemporary Applications}

Section III considers contemporary human rights issues that must be addressed to advance disease prevention and health promotion, examining the development and implementation of human rights in responding to leading public health threats. Where the health and human rights movement arose out of the early years of the AIDS response, Chapter 10 looks to how this movement has applied human rights to a range of communicable disease threats, analyzing the continuing importance of human rights amidst a shift toward global health security. With non-communicable diseases rapidly rising in a globalizing world, Chapter 11 looks to efforts to implement health-related human rights through legislative measures aimed at preventing and controlling tobacco use and obesity-related disease. Chapter 12 examines the conceptualization of new human rights to account for evolving understandings of public health and human dignity, looking to the rapid development and implementation of human rights to water and sanitation. Central to human dignity, Chapter 13 examines physical, mental, and intellectual disabilities, considering how human rights have altered medical practices and 
shifted disability policy from institutionalization to community-based rehabilitation. Section III ends by reflecting on the indivisibility of human rights in addressing sexual and reproductive health, with Chapter 14 examining the wide range of sexual and reproductive rights necessary to address issues of maternal mortality, family planning, violence against women, and LGBTQ health.

\section{Section IV. New Challenges}

Globalization has fundamentally altered public health, raising an imperative for global governance, and Section IV considers these global issues at the forefront of health and human rights. Recognizing the connection between economic development and global health, Chapter 15 analyzes the public health importance of the right to development and the rights-based approach to development, examining international obligations for development assistance and human rights efforts to meet the healthrelated SDGs. Chapter 16 extends this economic focus to the international trade system, exploring the health impacts of the World Trade Organization and bilateral trade treaties-specifically, the balance between intellectual property protections and healthrelated human rights. At the intersection of human rights law and humanitarian law, Chapter 17 considers international efforts to protect health and human rights in the context of conflict and emergencies. With non-consensual human experimentation viewed in the aftermath of World War II as a crime against humanity, human rights have evolved to protect informed consent, and Chapter 18 addresses the ethical standards that have arisen to protect human rights in clinical trials. Climate change is affecting the health of the entire planet, and given the overlapping harms to environmental health and planetary health, Chapter 19 considers how human rights can respond to these cataclysmic environmental health challenges. Reflecting the existential challenges of populist nationalism, Chapter 20 concludes this volume by addressing the ongoing populist obstacles to global health and human rights, examining the threat of populist nationalism to human rights norms and global health governance and the importance of health and human rights institutions in resisting this rising threat.

These chapters reflect the groundbreaking expansion of scholarship at the intersection of global health and human rights-highlighting the successes of human rights, the challenges of the twenty-first century, and the resilience of global health advocateswith this text providing a foundation for a new generation of practitioners. It is with this next generation that the fate of global health and human rights rests.

\section{Conclusion}

Health is a fundamental human right, without which no other rights would be possible. Where academics once shunned scholarship on health-related human rights, the end of the Cold War and harms of a globalizing world have raised new interest in studies at the intersection of global health and human rights. Emerging from the shadows of the AIDS pandemic, a global movement established the inextricable linkages between health and human rights. The rise of this health and human rights movement-spanning 
legal and public health scholarship-has contributed a long-sought framework for promoting those human rights that underlie public health. Yet, despite a burgeoning stream of scholarship in the field of health and human rights, there has been little reexamination of central norms, principles, and issues that define the field. Foundations of Global Health \& Human Rights seeks to provide this academic foundation for the field, preparing the next generation of policymakers, researchers, and advocates to sustain the global commitment to universal rights in public health.

The field of health and human rights is more than simply the application of human rights to global health. It is about a shared vision of both global health and human rights, where the practice of global health is framed by human rights norms and the framing of human rights law is influenced by the population perspective of public health. By explaining the legal principles that define human rights and applying these to global health threats, health and human rights education can provide students with concrete skills for bringing human rights to bear in health policies, programs, and practice. Courses in health and human rights can thus provide students with an academic foundation for critically engaging with the health and human rights challenges of a rapidly globalizing world, building an academic discipline through which injustices in global health can be understood through the lens of human rights. Such endeavors remain essential to achieving a heathier, more just society in which all people throughout the world are seen as equal in dignity and rights.

Institutions of global health and human rights have brought the world together in unprecedented cooperation since the end of World War II, offering universal frameworks to advance justice in health. While the populist challenge today is posing an unprecedented threat to continuing progress in human rights law and global health governance, with the COVID-19 pandemic highlighting our failures to realize global solidarity, the political obstacles of the past highlight the importance of sustained human rights engagement for global health advancement. Practitioners have a crucial role in resisting contemporary challenges to the field-engaging political advocacy to assure the future of human rights in global health. Through global health and human rights education, it will be possible to promote necessary understanding of the field, prepare practitioners to face ongoing challenges, and provide hope for the future.

\section{Acknowledgments}

The authors are grateful to Hanna Huffstetler and Caitlin R. Williams for their support in developing this description of global health, human rights, and the field that brings them together.

\section{References}

Alston, Philip. 2017. “The Populist Challenge to Human Rights." Journal of Human Rights Practice 9(1): 1-15.

ASPH Education Committee. 2006. Master's Degree in Public Health Core Competency Development Project, Version 2.3. Washington, DC: Association of Schools of Public Health. 
Backman, Gunilla, Paul Hunt, Rajat Khosla, Camila Jaramillo-Strouss, Belachew Mekuria Fikre, et al. 2008. "Health Systems and the Right to Health: An Assessment of 194 Countries." The Lancet 372: 2047-2085.

Birn, Anne-Emanuelle, Yogan Pillay, and Timothy H. Holtz. 2017. Textbook of Global Health. New York: Oxford University Press.

Brenner, Joel. 1996. "Human Rights Education in Public Health Graduate Schools: 1996 Surveys." Health and Human Rights 2(1): 129-139.

Brown, Theodore M., Marcos Cueto, and Elizabeth Fee. 2006. "The World Health Organization and the Transition from International to Global Public Health." American Journal of Public Health 96(1): 62-72.

CESCR (Committee on Economic, Social and Cultural Rights). 2000. "General Comment No. 14: The Right to the Highest Attainable Standard of Health (Art. 12)." 11 August. UN Doc. E/C.12/2000/4.

Cotter, L. Emily, Jonathan Chevrier, Wael Noor El-Nacher, Rohan Radhakrishna, Lisa Rahangdale, Sheri D. Weiser, and Vincent Iacopino. 2009. "Health and Human Rights Education in U.S. Schools of Medicine and Public Health: Current Status and Future Challenges." PLoSOne 4(3): e4916.

Detels, Roger and Chorh Chuan Tan. 2015. "The Scope and Concerns of Public Health." In Oxford Textbook of Global Public Health, Sixth Edition, edited by Roger Detels, Martin Gulliford, Quarraisha Abdool Karim, and Chorh Chuan Tan. Oxford: Oxford University Press.

Donnelly, Jack. 2003. Universal Human Rights in Theory and Practice. 2nd Edition. Ithaca, NY: Cornell University Press.

Farmer, Paul. 2003. Pathologies of Power: Health, Human Rights, and the New War on the Poor. Berkley: University of California Press.

Forman, Lisa. 2011. "Making the Case for Human Rights in Global Health Education, Research and Policy." Canadian Journal of Public Health 102(3): 207-209.

Forman, Lisa, Gorik Ooms, and Claire Brolan. 2015. "Rights Language in the Sustainable Development Agenda: Has Right to Health Discourse and Norms Shaped Health Goals?" International Journal of Health Policy Management 4(12): 799-804.

Frenk, Julio, Octavio Gómez-Dantés, and Suerie Moon. 2014. "From Sovereignty to Solidarity: A Renewed Concept of Global Health for an Era of Complex Interdependence." The Lancet 383(9911): 94-97.

Frenk, Julio and Suerie Moon. 2013. "Governance Challenges in Global Health." New England Journal of Medicine 368: 936-42.

Fried, Linda P., Margaret E. Bentley, Pierre Buekens, Donald S. Burke, Julio J. Frenk, Michael J. Klag, and Harrison C. Spencer. 2010. "Global Health is Public Health." The Lancet 375 (9714): 535-537.

Frisancho, Ariel, Jay Goulden, and Helene D. Gayle. 2010. “Operationalizing Rights-Based Approaches to Public Health: The Case of CARE in Peru." In Rights-Based Approaches to Public Health, edited by Elvira Beracochea, Corey Weinstein, and Dabney Evans. New York: Springer.

Getgen, Jocelyn and Benjamin Mason Meier. 2009. "Ratification of Human Rights Treaties: The Beginning, Not the End." The Lancet 374(9688): 447-448.

Gostin, Lawrence O. 2014. Global Health Law. Cambridge, MA: Harvard University Press.

Gostin, Lawrence O. 2001. "Public Health, Ethics, and Human Rights: A Tribute to the Late Jonathan Mann." Journal of Law, Medicine, and Ethics 29: 121-130.

Gostin, Lawrence O., S. Burris, and Zita Lazzarini. 1999. "The Law and the Public's Health: A Study of Infectious Disease Law in the United States." Columbia Law Review 99(59): 64.

Gostin, Lawrence O. and Jonathan Mann. 1994. "Towards the Development of a Human Rights Impact Assessment for the Formulation and Evaluation of Health Policies." Health and Human Rights 1(1): 58-81.

Gruskin, Sofia, Edward J. Mills, and Daniel Tarantola. 2007. "History, Principles, and Practice of Health and Human Rights." The Lancet 370(9585): 449-455. 
Habermas, Jürgen. 2018. “The Concept of Human Dignity and the Realistic Utopia of Human Rights." In Human Dignity: Perspectives from a Critical Theory of Human Rights, edited by Amos Nascimento and Matthias Lutz Bachmann. London: Routledge.

Iacopino, Vincent. 2002. Teaching Human Rights in Graduate Health Education. Boston: American Public Health Association François-Xavier Bagnoud Center for Health and Human Rights.

Mann, Johnathan. 1994. "A New Journal: A New Beginning." Health and Human Rights $1(1): 6-23$.

Mann, Jonathan, Lawrence Gostin, Sofia Gruskin, Troyen Brennan, Zita Lazzarini, and Harvey V. Fineberg. 1994. "Health and Human Rights." Health and Human Rights 1(1): 6-23.

Marks, Stephen P. 2001. "Jonathan Mann's Legacy to the 21st Century: The Human Rights Imperative for Public Health." Journal of Law, Medicine, and Ethics 29(131): 136-137.

Marks, Stephen P. 2009. "The Past and Future Separation of Human Rights into Categories." Maryland Journal of International Law 24(1): 209-243.

Marmot, Michael G., M. Kogevinas, and M.A. Elston. 1987. "Social/Economic Status and Disease." Annual Review of Public Health 8(111): 112-115.

McKeown, Thomas. 1979. The Role of Medicine: Dream, Mirage, or Nemesis? Princeton, NJ: Princeton University Press.

McMichael, Anthony and Robert Beaglehole. 2009. "The Global Context for Public Health." In Global Public Health: A New Era, 2nd Edition, edited by Robert Beaglehole and Ruth Bonita. Oxford: Oxford University Press.

Meier, Benjamin Mason, Dabney P. Evans, Matthew M. Kavanagh, Jessica M. Keralis, and Gabriel Armas-Cardona. 2018. "Human Rights in Public Health: Deepening Engagement at a Critical Time." Health and Human Rights Journal 20(2): 85-91.

Meier, Benjamin Mason and Lawrence O. Gostin. 2018. Human Rights in Global Health: Rights-Based Governance for a Globalizing World. New York: Oxford University Press.

Meyer, Ilan H. and Sharon Schwartz. 2000. "Social Issues as Public Health: Promise and Peril." American Journal of Public Health 90(8): 1189-1191.

Moon, Suerie, Nicole A. Szlezák, Catherine M. Michaud, Dean T. Jamison, Gerald T. Keusch, William C. Clark, and Barry R. Bloom. 2010. "The Global Health System: Lessons for a Stronger Institutional Framework." PLoS Medicine 7(1): e1000193.

Porter, Dorothy. 1997. Social Medicine and Medical Sociology in the Twentieth Century. Amsterdam: Clio Medica.

Potts, Helen. 2008. Accountability and the Right to the Highest Attainable Standard of Health. Essex: Human Rights Centre, University of Essex.

Rodríguez-Garavito, César and Krizna Gomez. 2018. Rising to the Populist Challenge: A New Playbook for Human Rights Actors. Bogotá: Dejustici’a.

Rosen, George. 1958. A History of Public Health. New York: MD Publications.

Ruger, Jennifer Prah. 2018. Global Health Justice and Governance. Oxford: Oxford University Press.

Sand, René. 1934. L'Économie Humaine par la Médicine Sociale. Paris: Éd. Rieder.

Steiner, Henry J., Philip Alston, and Ryan Goodman. 2008. International Human Rights in Context: Law, Politics, Morals. New York: Oxford University Press.

Susser, Mervyn and Ezra Susser. 1996. "Choosing a Future for Epidemiology: II. From Black Box to Chinese Boxes and Eco-Epidemiology." American Journal of Public Health 86(5): 674-677.

Tarantola, Daniel and Sofia Gruskin. 2006. "Health and Human Rights Education in Academic Settings." Health and Human Rights 9(2): 297-300.

UN General Assembly. 1948. "Universal Declaration of Human Rights." 10 December. Res. 217 A (III).

UN General Assembly. 1966. "International Covenant on Economic, Social and Cultural Rights.” 16 December. Res. 2200A (XXI). 
UN General Assembly. 1993. "Vienna Declaration and Programme of Action.” 12 July. UN Doc. A/CONF.157/23

UN General Assembly. 2015. “Transforming Our World: The 2030 Agenda for Sustainable Development.” 25 September. UN Doc. A/RES/70/1.

WHO (World Health Organization). 1946. Constitution of the World Health Organization. 22 July. Available at: htp://www.who.int/governance/eb/who_constitution_en.pdf.

WHO. 1978. Declaration of Alma Ata: International Conference on Primary Health Care, Alma Ata, USSR. 6-12 September. Geneva: World Health Organization.

WHO. 1980. "Summary of the Deliberations of the Preparatory Meeting of Medical Personnel Concerned with Health and Human Rights." 16-17 September. Geneva: Henry Dunant Institute.

World Medical Association. 1999. "WMA Resolution on the Inclusion of Medical Ethics and Human Rights in the Curriculum of Medical Schools World-Wide." WMA General Assembly, 66th session.

Winkler, Inga T. and Carmel Williams. 2017. "The Sustainable Development Goals and Human Rights: A Critical Early Review." International Journal of Human Rights 21(8): 1023-1028.

Winslow, C.E.A. 1924. "The Evolution and Significance of the Modern Public Health Campaign." American Journal of Public Health 14(4): 343.

Yamin, Alicia. 2016. Power, Suffering, and the Struggle for Dignity: Human Rights Frameworks for Health and Why They Matter. Philadelphia: University of Pennsylvania Press.

Yamin, Alicia. 2008. "Beyond Compassion: The Central Role of Accountability in Applying a Human Rights Framework to Health.” Health and Human Rights 10(2): 1-20.

Youde, Jeremy. 2012. Global Health Governance. Cambridge: Polity Press. 